\title{
Lipidose hepática em obstrução parcial do orifício retículo-omasal por ingestão massal de caroços de manga em minivaca - relato de caso
}

Sophia Cavalcante Costa de Sousa, Mateus Lima de Oliveira Barreiros, Bruna Higino de Souza Silva, Raíssa Karolliny Salgueiro Cruz, Edson de Figueiredo Gaudêncio Barbosa, Saulo de Tarso Gusmão da Silva

Clínica Escola de Medicina Veterinária do Centro Universitário Cesmac (CESMAC), Marechal Deodoro, AL, Brasil

*Autor correspondente

e-mail: sophiaccdesousa@gmail.com

\section{Resumo}

Deu-se entrada na Clínica Escola de Medicina Veterinária do Centro Universitário Cesmac, em Marechal Deodoro/AL, um animal da espécie bovina miniatura, fêmea, com aproximadamente quatro anos de idade, escore corporal 2,5 e criada de forma extensiva. A queixa principal era referente à ausência de apetite e decúbito esternal por mais de 24 horas. Foi constatado no exame clínico mucosas oculares hipercoradas, cicatriz na comissura mandibular e ausências de dentes incisivos, desidratação, presença de ectoparasitas e temperatura de 39,5 ํ․ Na palpação retal e no exame ultrassonográfico via transretal foi possível identificar a presença de um feto vivo e a termo. No dia seguinte, observou-se a eliminação do tampão vaginal mucoso, e após uma nova palpação retal foi identificado uma distorcia materno fetal, optando-se por uma cesariana de emergência. Apesar de a termo, o bezerro veio a óbito por angústia respiratória minutos após o parto. 0 animal foi submetido a antinflamatório e antibioticoterapia, no entanto não apresentou evolução positiva, mantendo-se em decúbito lateral e vindo a óbito quatro dias após a cirurgia. As lesões encontradas no exame necroscópico foram as seguintes: úlceras no antímero esquerdo da região do toros lingual, formações papilomatosas no final do esôfago e no esfíncter cárdico invadindo o rúmen. 0 fígado se encontrava difusamente pálido, amarelado, com a consistência friável. No interior do rúmen foi observada uma quantidade massiva de caroços de manga (total de 755 caroços) obstruindo parcialmente o orifício retículoomasal, além de outros corpos estranhos obstrutivos como sacolas plásticas. Úlceras abomasais e presença de vermes abomasais. No histopatológico de fragmentos hepáticos, observou-se hepatócitos difusamente tumefeitos com vacúolos não corados no interior do citoplasma com o núcleo deslocado para periferia. Diante do exposto, conclui-se que em consequência de um balanço energético negativo devido a avançada prenhez, somado à obstrução parcial do orifício retículo-omasal, uma elevada demanda energética e mobilição de gordura estabeleceu um quadro de lipidose hepática severa, que foi determinante para a morte do animal. 